\title{
A Comparative Fiber Morphological Analysis of Major Agricultural Residues (Used or Investigated) as Feedstock in the Pulp and Paper Industry
}

\author{
Dimitrios Tsalagkas, a,b,* Zoltán Börcsök, ${ }^{\text {a } Z o l t a ́ n ~ P a ́ s z t o r y, ~}{ }^{a}$ Vladimir Gryc, ${ }^{\mathrm{b}}$ \\ Levente Csóka, ${ }^{\text {,d }}$ and Kyriaki Giagli ${ }^{b}$
}

\begin{abstract}
The suitabilities of major agricultural residues were assessed as papermaking feedstocks. All the examined agricultural residues were assumed as potential candidates for substituting hardwood fibers in mixed pulp blends from a fiber morphological perspective. Wheat, barley, rice, rapeseed, maize, sunflower, sugarcane bagasse, coconut husk, and two genotypes of miscanthus grass underwent identical maceration. The fiber length, fiber width, cell wall thickness, and lumen diameter were measured to calculate the slenderness ratio, flexibility coefficient, and Runkel ratio. The average fiber length ranged from $0.50 \mathrm{~mm} \pm 0.32 \mathrm{~mm}$ (MG-S-02-V) to $1.15 \mathrm{~mm} \mathrm{~mm} \pm 0.58 \mathrm{~mm}$ (sugarcane bagasse). The fiber width ranged from $10.77 \mu \mathrm{m} \pm 3.28 \mu \mathrm{m}$ (rice straw) to $22.99 \mathrm{~mm} \pm 5.20 \mathrm{~mm}$ (sunflower stalk). The lumen diameter ranged from $4.52 \mu \mathrm{m} \pm 2.52 \mu \mathrm{m}$ (rice straw) to $13.23 \mu \mathrm{m} \pm 4.87 \mu \mathrm{m}$ (sunflower stalk). The cell wall thickness ranged from $3.02 \mu \mathrm{m} \pm 0.95 \mu \mathrm{m}$ (rice straw) to $4.80 \mu \mathrm{m} \pm 1.48 \mu \mathrm{m}$ (sunflower stalk). The slenderness ratio, flexibility coefficient, and Runkel ratio values ranged between 28.08 to $58.11,37.97$ to 60.8 , and 0.62 to 1.68 , respectively. Wheat, maize, rapeseed, sugarcane bagasse, and coconut husk were found to be appropriate residue sources for papermaking feedstocks.
\end{abstract}

Keywords: Agricultural waste biomass; Non-wood fibers; Papermaking potential; Morphological indices

Contact information: a: Innovation Center, University of Sopron, Bajcsy-Zs, 4, Sopron 9400 Hungary; $b$ : Department of Wood Science and Technology, Faculty of Forestry and Wood Technology, Mendel University in Brno, Zemědělská 3, Brno 61300 Czech Republic; c: Institute of Cellulose and Paper Technology, Celltech-paper Ltd., Sopron 9400 Hungary; d: ELTE University, Faculty of Informatics, Budapest 1053 Hungary; *Corresponding author: dimitrios.tsalagkas@mendelu.cz

\section{INTRODUCTION}

Although the primary global trend is to exploit agricultural residues (AgRs) as feedstock materials in bioenergy or biorefinery fields, not all residues are suitable for such purposes (Lal 2005). For instance, while maize and sugarcane crop residues appear as promising raw materials for bioethanol or biogas production, contrariwise, rice and wheat (44\% of the total global agricultural residues production), only play a minor role in the production of biofuels (Cherubin et al. 2018). Moreover, second-generation biofuels, based on lignocellulosic by-products and energy (perennial herbaceous) crops, are not expected to become economically viable or commercially available in the forthcoming years; thus, second-gen biofuels were not able to contribute to reaching the $20 \%$ renewable energy consumption EU-targets by 2020 (Elbersen et al. 2012).

The calculated technical potential production from the eight major crops in the world, i.e., wheat, maize, rice, soybean, barley, rapeseed (or canola), sugarcane, and sugar 


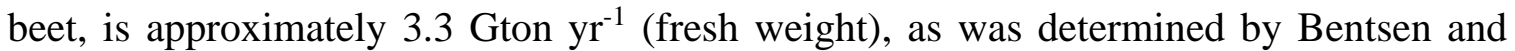
Felby (2010). It was also demonstrated that the Asian continent presented the largest share of crop residues production (47\% of the total share), followed by the USA (29\%), Europe (16\%), Africa (6\%), and Oceania (2\%) (Cherubin et al. 2018). Bentsen et al. (2014) developed a model and pointed out that maize, rice, and wheat residues were accounting for more than three-quarters of the total production in 227 countries around the world. Likewise, Camia et al. (2018) and García-Condado et al. (2019) found that wheat, grain maize, rapeseed, barley, and sunflower residues, together constituted more than $80 \%$ of the total EU-28 residual production by using empirical models. In Asia, China and India are viewed as the two primary countries in terms of residue biomass availability, primarily in the form of wheat, maize, and rice straw in China, and sugarcane bagasse, wheat, and rice straw in India (Gregg and Smith 2010; Jiang et al. 2012; Hiloidhari et al. 2014; Chen 2016). In the USA, potential farmgate supplies of primary crop residues, e.g., maize stover, wheat, barley, oats, and sorghum straw, and energy crops, e.g., switchgrass, miscanthus, and biomass sorghum, were estimated to reach up to $214 \mathrm{Mt}$ of crop residues and $729 \mathrm{Mt}$ of herbaceous energy crops by the year 2040 by using the POLYSYS simulation assumption model (Langholtz et al. 2016).

For the fulfilment of the oriented global targets, set within the strategies of a sustainable and resource efficient based circular economy, it is critical to utilize alternative sources of fibrous, lignocellulosic biomass, e.g., non-wood plants, as raw materials for paper and paperboard manufacturing (Przybysz et al. 2018; Sharma et al. 2018; Jeetah and Jaffur 2021). The cell types present in non-woody plants, including AgRs, are more heterogeneous than the cell types present in woody plants. The basic structure of a nonwood plant consists of vascular bundles and parenchyma tissue and contains many types of cells with a wide distribution of cellular dimensions. Furthermore, the type and size of fibers and vessel cells greatly vary within a single plant and between species, since in grasses the same type of cell may originate in different tissues and organs of the plant, which either positively or negatively influence the pulp and paper properties (Ilvessalo Pfäffli 1995; Rousu et al. 2013). The length of short fibers, a low bulk density, a high fines content, and a high amounts of parenchyma cells and mineral substances are a few of the most important inherent features of these non-wood plant sources (Sridach 2010). Additionally, AgRs contain lower proportions of lignin compared to wood-based sources, which is beneficial during the bleaching stage of pulp production (Kaur et al. 2019).

Currently, a major portion of non-wood fibers have already been used for papermaking for a long time, especially in the developing countries of Asia, Africa, and Latin America, which may feature a shortage of wood raw materials (Reddy et al. 2014). Conventional pulping processes, e.g., soda, soda-antraquinone, and kraft, are already used for non-wood pulping, yet alternative pulping processes for non-wood pulping are more desirable. During the last years, several promising approaches in all fields of established papermaking procedures have been investigated at a laboratory or pilot scale, to overcome the limitations and challenges of non-wood pulping. These methods have constituted nonwood plant fibers as a reasonable candidate to replace wood fibers, especially replacing hardwood as the pulp feedstock (El-Sayed et al. 2020; Ferdous et al. 2020; Sharma et al. 2020a; Jahan et al. 2021).

Various non-wood plant agricultural sources have already been considered as potential pulp and paper feedstocks in the past (Ogbonnaya et al. 1997; Gonzalo et al. 2017; Saeed et al. 2017a; Gülsoy and Şimşir 2018; Lavrič et al. 2018). In addition, energy crops, and their residues, including Miscanthus spp. have also been considered as potential 
feedstocks for paper pulps (Cappelletto et al. 2000; Goel et al. 2000; Ai and Tschirner 2010; Albert et al. 2011). Yet most of the studies have been focused on the investigation of cereal/rice straws, sunflower stalks, rapeseed/canola straw, and sugarcane bagasse. de Assis et al. (2019) found that semi-bleached wheat straw pulps (SBWP) had intermediate FL and coarseness values, with very high fines content, which results in lower bulk and water absorbency. However, this is not a limitation of producing low quality tissue products that require an intermediate combination of water absorbency, softness, and strength and could be used to replace deinked pulp. Pulps obtained from rapeseed stalks can be used as secondary fibers, replacing recycled paper in pulp blends with virgin wood fibers (González et al. 2013). Jeetah et al. (2015) demonstrated that rice husk-bagasse pulp blends (20:80 ratio) are suitable for producing insulating boards or medium packaging cardboards for decorative purposes. According to Bates et al. (2020) triticale pulp could be used for specific categories of printing substrates or bagasse fibers can be used for rough papers like those that are used in packaging.

Apart from China and India, the amount of produced pulp from fiber sources other than wood is still limited globally. According to FAOSTAT (2019) data, more than $80 \%$ of non-wood pulp worldwide is produced in Asian countries since the 1980s. More particularly, in these countries, the average pulp production coming from fibers other than wood was estimated at around 14258000 metric tons from 1995 to 2018. In Europe, CEPI members, which constitute $92 \%$ of the European pulp and paper industries in terms of production, the total non-wood pulp production amount hardly reached $0.8 \%$ of the total pulp production (273000 tons) (CEPI 2020).

An overall evaluation of the papermaking potential of a raw material as pulp feedstock, besides its morphological analysis, requires the evaluation of the physical properties of the obtained paper handsheets, the optimization of pulping and bleaching conditions, and the pulping chemical recovery (recycling of pulping chemicals, utilization of black liquor) processes. (Kamoga et al. 2016; Jahan et al. 2021). Non-wood fibers have unlimited differences in terms of their physical and chemical properties, and they all cover various average fiber dimensions and a wide selection of cell types and sizes (El-Sayed et al. 2020).

The physical properties of any paper primarily depend on its fiber morphology, fiber-fiber bonding, pulp refining, wet pressing, and formation (Sharma et al. 2020b). The fiber anatomical dimensions greatly impact the quality and performance of the final paper product, since these dimensions are highly correlated with its physical strength, and printing quality (Pulkkinen et al. 2009; Hu et al. 2013; Pereira et al. 2016). For instance, the fiber morphological properties directly affect the runnability on the paper machine, the refining response, the pulp bonding ability, and the physical, optical, and strength properties of the paper (Gülsoy and Şimşir 2018).

The fibers length (FL) and average FL distribution of a plant are considered essential morphological features, since they have a major impact on the paper strength, paper sheet formation, and drainage. Nevertheless, FL alone is not a good predictor of paper properties (Simmonds and Hyttinen 1964; Ai and Tschirner 2010; Saeed et al. 2017a). The fiber width (FW) and cell wall thickness (CWT) are highly correlated with fiber flexibility and bending resistance. Arundo donax fibers obtained from internodes parts of the plant, presented narrower LD and less wide CWT compared to those of nodes fibers, suggesting better papermaking properties (Shatalov and Pereira 2006). Furthermore, shorter LD have a positive influence on the beating of the pulp. In contrast, thicker cell walled fibers diminish the folding endurance, the burst and tensile index, and the 
synergistic effect on the tear strength of a paper (Agnihotri et al. 2010; Tofanica et al. 2011; Saeed et al. 2017a).

In addition, the importance of plant fiber cell dimensions and their derived values on pulp and paper mechanical strength is well documented (Ververis et al. 2004; Nasser et al. 2015). Therefore, the morphological indices derivatives, i.e., the slenderness ratio (SR), flexibility coefficient (FC), and Runkel ratio (RR), obtained from geometrical measurements of the fibers, are often used as an evaluating criterion to assess the suitability of a plant-based source as feedstock in papermaking production.

Additionally, pulp refining, the mechanical treatment of fibers, is a necessary step conducted on the raw source to improve the pulp quality. Depending on the pulp source, pulp consistency, refining equipment, and intensity, refining differently affects the final morphology and characteristics of the treated fibers. A few of the changes during the internal and external fibrillation of the fibers due to refining are the shortening of the fiber length, fines formation, and fibers' straightening (Gharehkhani et al. 2015). Therefore, the fiber morphological parameters, i.e., fiber length, fiber width, lumen diameter, and cell wall thickness, of the raw non-wood plant fibers are important quality factors influencing both the pulp and paper properties and are essential to predicting the strength properties of the produced paper grades.

Thus, an initial morphological evaluation of raw non-wood fiber dimensions is a needful assessment to take into consideration, regarding the properties of the produced pulp and paper. Nevertheless, up to now, there are contradictory findings when it comes to the previous extended literature. The objective of this study was to conduct a unified fiber morphological parameter analysis, by applying the same maceration treatment and calibration/measurement method on the raw AgRs. Finally, this article aimed at detecting the potential differences between the novel results of the authors and the existing literature, hoping to infer the most appropriate AgRs feedstock for the pulp and paper industry.

\section{EXPERIMENTAL}

\section{Materials and Methods}

\section{Raw materials}

For this study, the following $10 \mathrm{AgRs}$ sources were investigated: wheat straw (Triticum spp.), barley straw (Hordeum vulgare), maize stalk (Zea mays), rice straw (Oryza sativa), sunflower stalk (Helianthus annuus), rapeseed (Brassica napus L.), and sugarcane bagasse (Saccharum officinarum). In addition, coconut husk (Cocos nucifera) fibers, and from the perspective of energy crops, two genotypes of Miscanthus $x$ giganteus grass residues were examined (labelled as MG-S-O2-V and MG-S-01-P, respectively) (Fig. 1).

Wheat straw, barley straw, rapeseed straw, maize stalks, and sunflower stalks samples were collected by local farmers in the region of Györ-Moson-Sopron, Hungary. The Miscanthus $x$ giganteus stalks, were provided by Energianoveny Ltd., (Lengyeltóti, Hungary). The rice straw, coconut husk coir fibers, and sugarcane bagasse were obtained from local producers in Vietnam, while their chemical treatment and measurement analysis were performed in Hungary. All samples were air-dried, chopped into 3 to $5 \mathrm{~cm}$ length pieces, and finally stored in sealed polyethylene bags until sample preparation. 


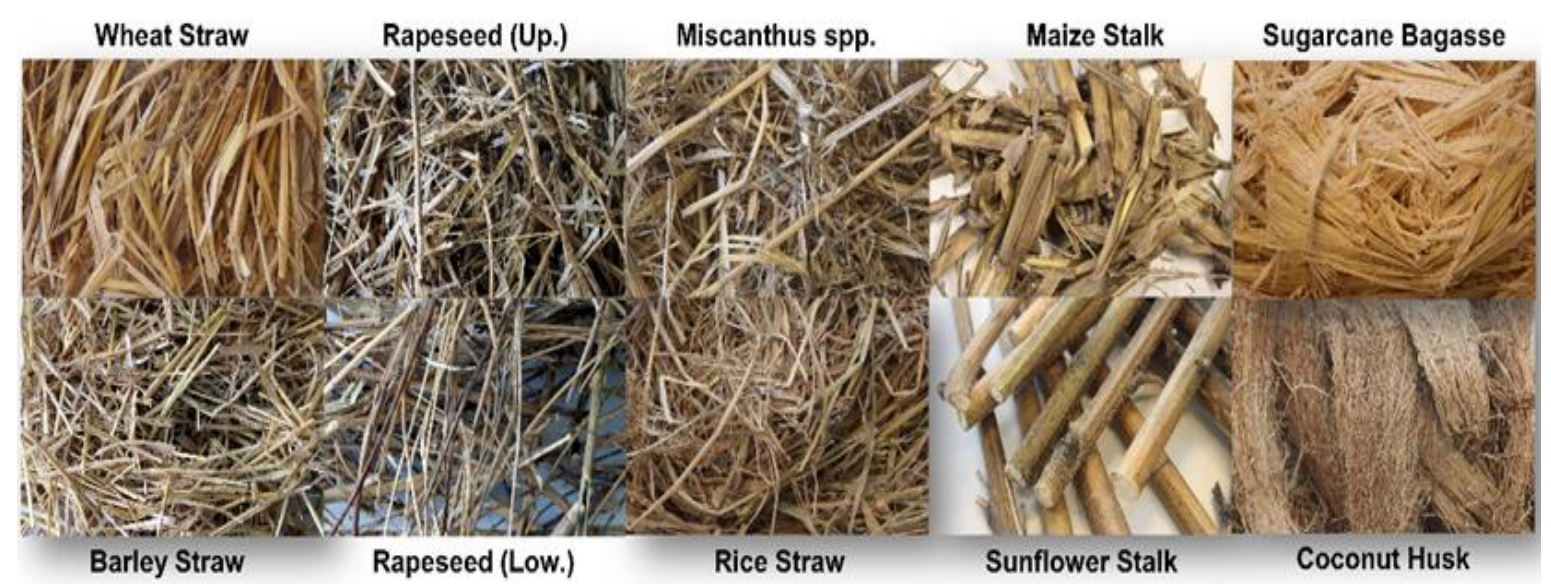

Fig. 1. Raw material of the agricultural residues (AgRs) examined in this study

\section{Sample preparation}

The non-wood AgRs were macerated according to the method performed by Danielewicz et al. (2018). Approximately $2 \mathrm{~mm}$ x $2 \mathrm{~mm}$ x $5 \mathrm{~mm}$ sticks were cut using a sharp knife. Thereafter, the sticks were placed in vials with the maceration solution, capped, and placed in a drying oven at a temperature of $60{ }^{\circ} \mathrm{C}$ for one week. The ratio of the volume of maceration solution to non-wood samples was 100 to $1(\mathrm{v} / \mathrm{w})$; the maceration solution was composed of one-part hydrogen peroxide $\left(30 \% \mathrm{H}_{2} \mathrm{O}_{2}\right.$ solution), four parts of deionized water, and five parts of pure glacial acetic acid. In due course, the samples were washed and mixed with distilled water to separate the fiber bundles into individual fibers. The macerated solution samples consisted of an overall mixture of all plant parts, including the pith, nodes, and internodes.

\section{Measurements and data processing}

For the morphological analysis, optical microscope (OM) images were captured at x40 and x200 magnifications using a Nikon Eclipse 80i optical microscope (Nikon Instruments Inc., Tokyo, Japan). At least 200 fibers per AgR source were randomly measured. The number varied according to the density of each AgR solution. Image-Pro Plus software (version 6, Media Cybernetics Inc., Rockville, Maryland) was used for measuring the fiber morphological parameters. The OM images captured at $\mathrm{x} 40$ magnification were used for the FL measurements, while those captured at x200 were used for measuring the FW, LD, and CWT. The average values of the FL, FW, LD, and CWT parameters were calculated for each AgR source.

To assess the suitability of the AgRs as pulp feedstocks for paper production, the following three fiber morphological indices (SR, FC, and RR) were calculated according to Eqs. 1, 2, and 3,

$$
\begin{aligned}
& S R=F L / F W \\
& F C=(L D / F W) \times 100 \\
& R R=2 \times C W T / L D
\end{aligned}
$$

(Ogbonnaya et al. 1997; Ververis et al. 2004; Albert et al. 2011; Mousavi et al. 2013; Saeed et al. 2017a). 


\section{RESULTS AND DISCUSSION}

\section{Fiber Dimensions Analysis}

Representative OM images of the macerated fibers measured for the morphological analysis of the AgR sources are shown in Figs. 2 through 6. The OM images depict the diversity among the $\mathrm{AgR}$ raw materials.

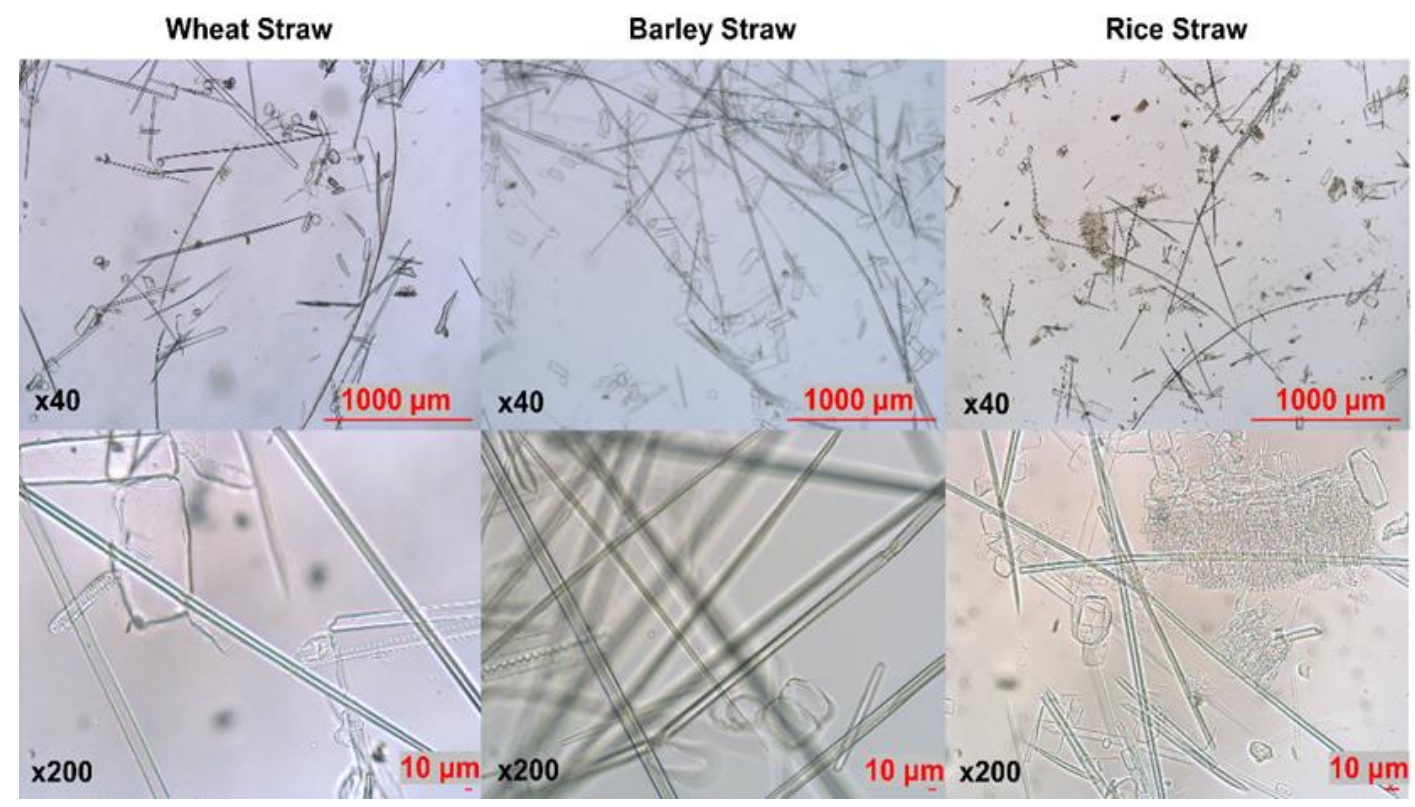

Fig. 2. Optical microscope images of the cereal straw residue fibers at $\times 40$ and $\times 200$ magnifications

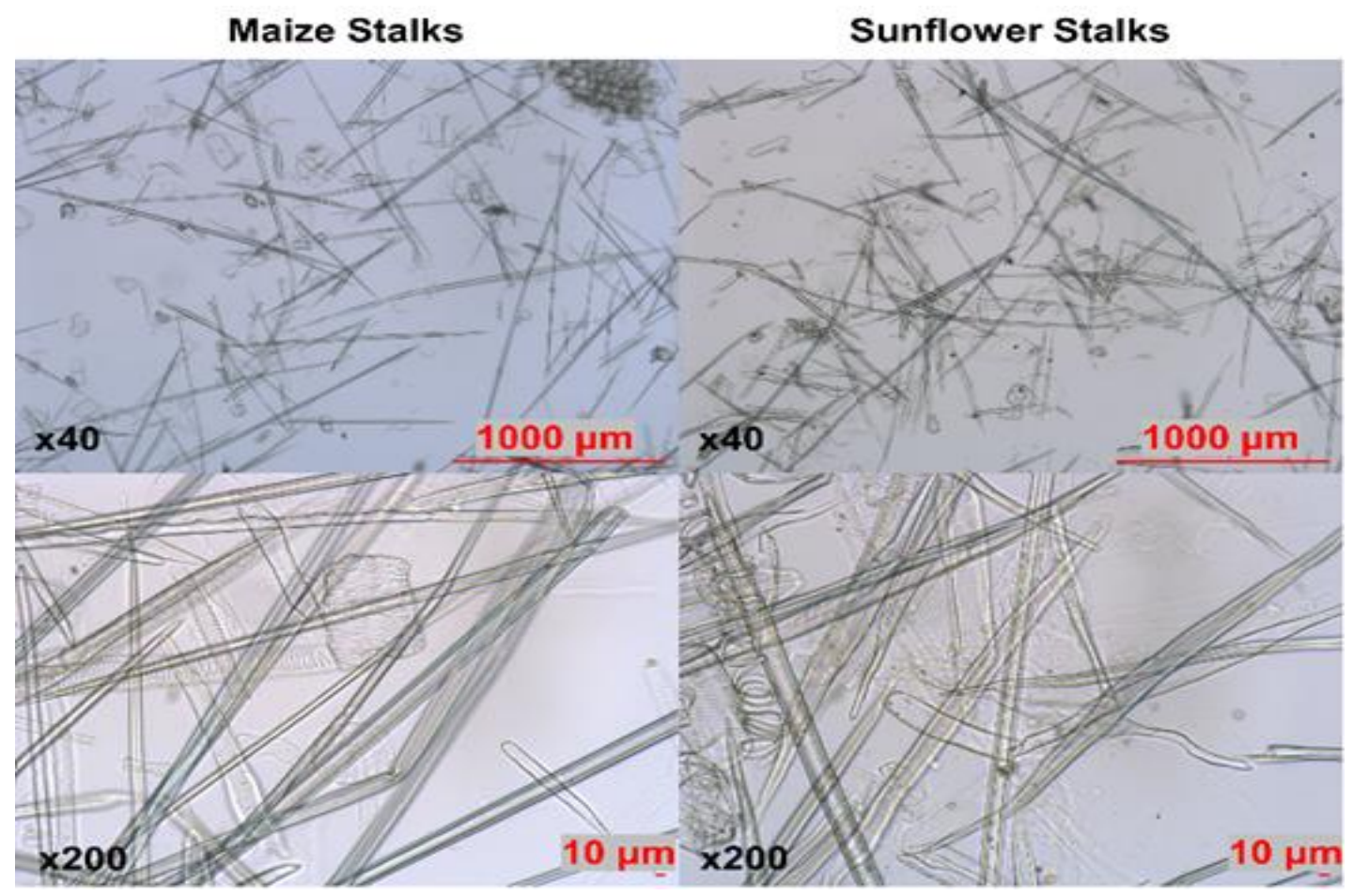

Fig. 3. Optical microscope images of the stalk residue fibers at $\times 40$ and $\times 200$ magnifications 


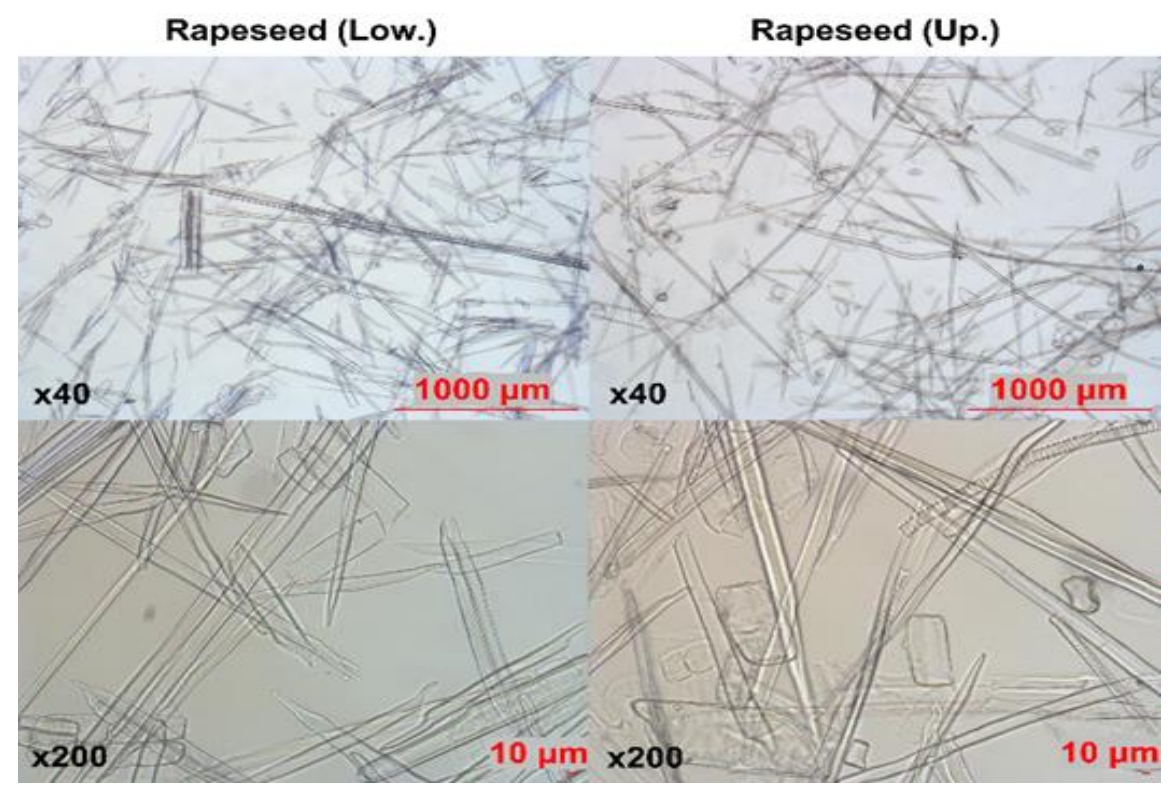

Fig. 4. Optical microscope images of the rapeseed residue fibers at $x 40$ and $\times 200$ magnifications

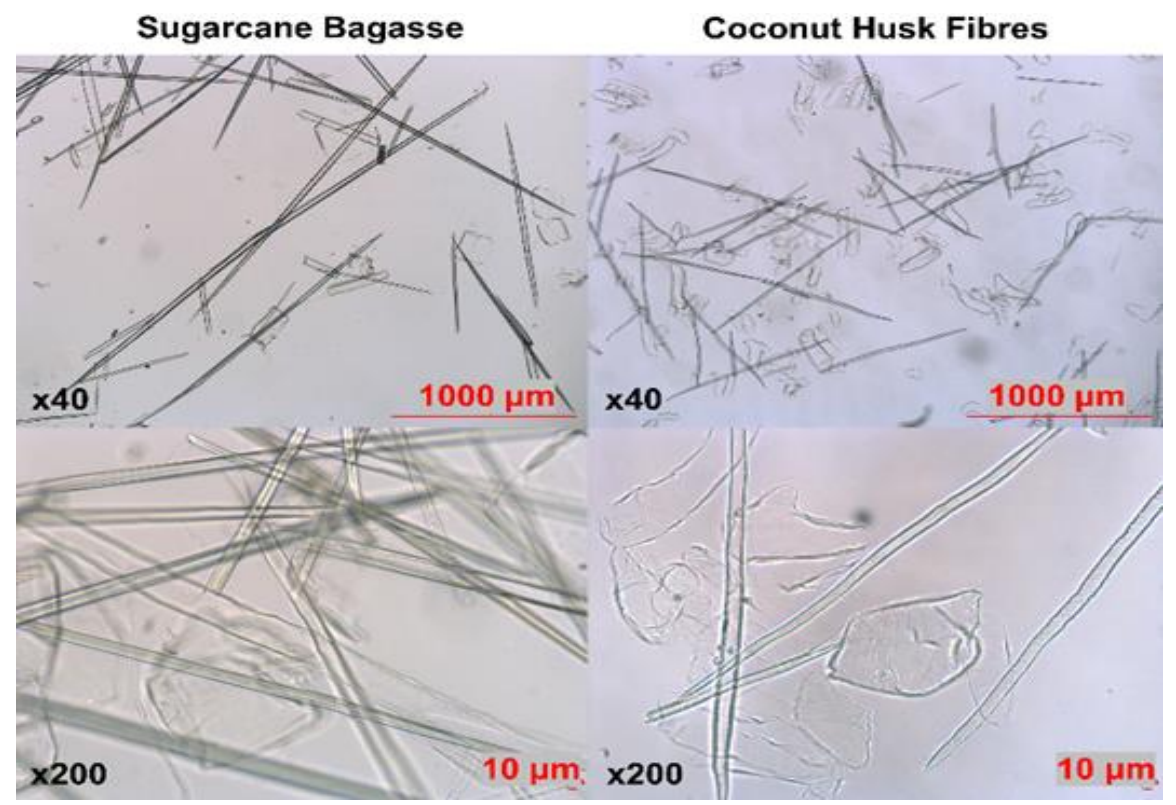

Fig. 5. Optical microscope images of the Asian originated residue fibers at $x 40$ and $\times 200$ magnifications

The observed average FL values of the measured non-wood plant residues (Table 1) were found to be approximately within the $0.7 \mathrm{~mm}$ to $3.0 \mathrm{~mm}$ hardwood FL range (Simmonds and Hyttinen 1964; Ring and Bacon 1997). In addition, they were found to be within the FL range of the other investigated non-wood fibers obtained from vegetable AgR sources (Gonzalo et al. 2017; Saeed et al. 2017a). The sugarcane bagasse fibers presented the longest average FL $(1.15 \mathrm{~mm} \pm 0.58 \mathrm{~mm})$, while the Miscanthus MG-S-02$\mathrm{V}$ fibers had the shortest $(0.50 \mathrm{~mm} \pm 0.32 \mathrm{~mm})$ average FL. As demonstrated by Marín et al. (2009) and de Assis et al. (2019), fibers with lengths ranging between $0.2 \mathrm{~mm}$ and 1.2 $\mathrm{mm}$, as well as those with a length greater than $1.2 \mathrm{~mm}$, are considered short and long fibers, respectively. Hardwood fibers usually are short ranging from 0.7 to $1.6 \mathrm{~mm}$, with 
an average fiber length of $1 \mathrm{~mm}$, while softwood fibers are much longer typically ranging from 2.7 to $4.6 \mathrm{~mm}$ (Elmas et al. 2018). Therefore, the assessed AgRs can be counted as having a short FL, and short length fibers result in a denser, smoother, and more uniform paper sheet formation (Ai and Tschirner 2010).

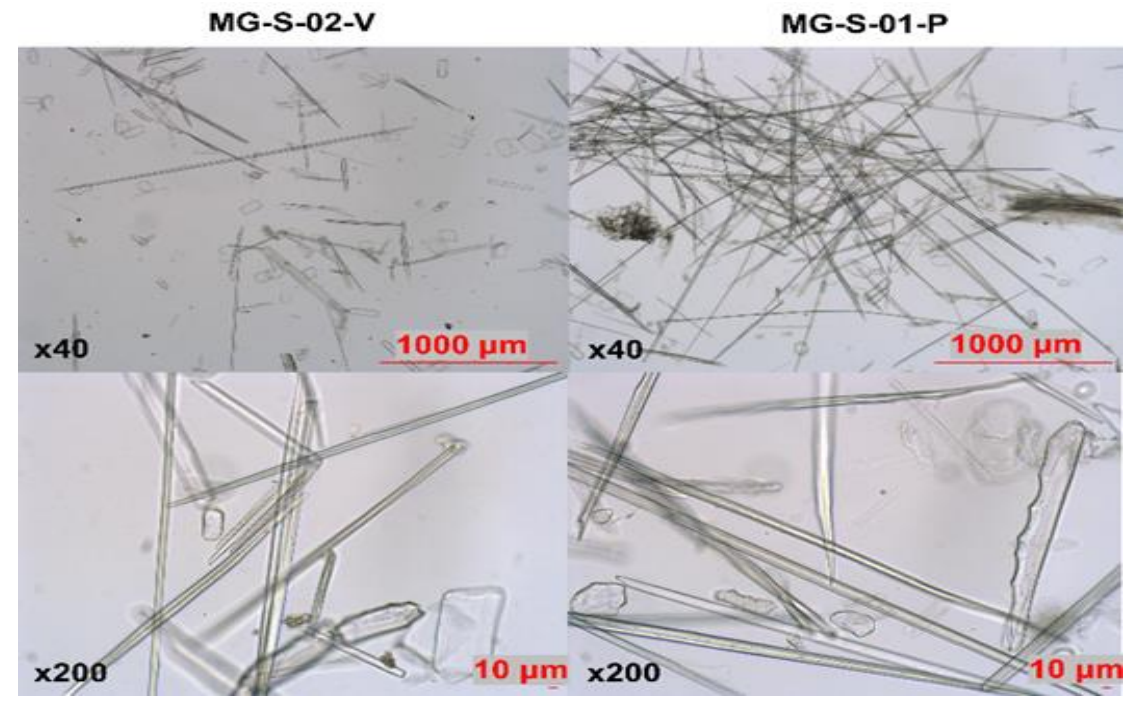

Fig. 6. Optical microscope images of the Miscanthus genotypes straw fibers at x40 and x200 magnifications

Table 1. Estimated Fiber Morphological Parameters of the Investigated Agricultural Residues (AgRs)

\begin{tabular}{|c|c|c|c|c|}
\hline Agricultural Residue Source & $\begin{array}{c}\mathrm{FL} \\
(\mathrm{mm})\end{array}$ & $\mathrm{FW}(\mu \mathrm{m})$ & $\begin{array}{c}\mathrm{LD} \\
(\mu \mathrm{m})\end{array}$ & $\begin{array}{c}\text { CWT } \\
(\mu \mathrm{m})\end{array}$ \\
\hline Wheat straw (Triticum spp.) & $\begin{array}{c}0.78 \\
( \pm 0.44)\end{array}$ & $\begin{array}{c}16.87 \\
( \pm 5.46)\end{array}$ & $\begin{array}{c}8.34 \\
( \pm 5.12)\end{array}$ & $\begin{array}{c}4.13 \\
( \pm 1.40)\end{array}$ \\
\hline Barley straw (Hordeum vulgare) & $\begin{array}{c}0.67 \\
( \pm 0.47)\end{array}$ & $\begin{array}{c}15.26 \\
( \pm 4.47)\end{array}$ & $\begin{array}{c}6.97 \\
( \pm 4.01)\end{array}$ & $\begin{array}{c}4.07 \\
( \pm 1.35)\end{array}$ \\
\hline Rice straw (Oryza sativa L.) & 0.54 & 10.77 & 4.52 & 3.02 \\
& $( \pm 0.44)$ & $( \pm 3.28)$ & $( \pm 2.52)$ & $( \pm 0.95)$ \\
\hline Maize stalks (Zea mays spp) & 0.75 & 17.18 & 9.73 & 3.68 \\
$( \pm 0.31)$ & $( \pm 5.65)$ & $( \pm 4.69)$ & $( \pm 1.13)$ \\
\hline Sunflower stalks (Helianthus annuus L.) & 0.64 & 22.99 & 13.23 & 4.80 \\
& $( \pm 0.36)$ & $( \pm 5.20)$ & $( \pm 4.87)$ & $( \pm 1.48)$ \\
\hline Rapeseed up. (Brassica napus L.) & 0.71 & 18.36 & 9.73 & 4.25 \\
& $( \pm 0.53)$ & $( \pm 5.58)$ & $( \pm 4.57)$ & $( \pm 1.27)$ \\
\hline Rapeseed low. (Brassica napus L.) & 0.57 & 18.99 & 11.04 & 3.86 \\
$( \pm 0.42)$ & $( \pm 4.73)$ & $( \pm 4.24)$ & $( \pm 1.22)$ \\
\hline Sugarcane bagasse (Saccharum & 1.15 & 19.86 & 10.25 & 4.50 \\
officinarum L.) & $( \pm 0.58)$ & $( \pm 6.25)$ & $( \pm 5.50)$ & $( \pm 1.80)$ \\
\hline Coconut husk/coir fibers (Cocos nucifera) & 0.67 & 17.60 & 10.71 & 3.30 \\
$( \pm 0.27)$ & $( \pm 3.12)$ & $( \pm 2.73)$ & $( \pm 0.69)$ \\
\hline Miscanthus $x$ giganteus Stalks MG-S-02-V & 0.50 & 15.17 & 5.76 & 4.64 \\
& $( \pm 0.32)$ & $( \pm 4.89)$ & $( \pm 3.79)$ & $( \pm 1.45)$ \\
\hline Miscanthus $x$ giganteus Stalks MG-S-01-P & 0.72 & 15.52 & 7.03 & 4.16 \\
& $( \pm 0.43)$ & $( \pm 5.06)$ & $( \pm 3.98)$ & $( \pm 2.21)$ \\
\hline
\end{tabular}


Table 2. Average Values of the Fiber Morphological Parameters per Agricultural Residue (AgR) Source According to Literature References

\begin{tabular}{|c|c|c|c|c|c|}
\hline $\begin{array}{c}\text { Agricultural Residue } \\
\text { Source }\end{array}$ & $\begin{array}{c}\mathrm{FL} \\
(\mathrm{mm})\end{array}$ & $\begin{array}{l}\text { FW } \\
(\mu \mathrm{m})\end{array}$ & $\begin{array}{l}\text { LD } \\
(\mu \mathrm{m})\end{array}$ & $\begin{array}{l}\text { CWT } \\
(\mu \mathrm{m})\end{array}$ & References \\
\hline \multirow{4}{*}{$\begin{array}{c}\text { Wheat straw (Triticum } \\
\text { spp.) }\end{array}$} & $\begin{array}{c}0.74 \\
( \pm 0.28)\end{array}$ & $\begin{array}{c}13.20 \\
( \pm 2.21)\end{array}$ & $\begin{array}{c}4.02 \\
( \pm 1.69)\end{array}$ & $\begin{array}{c}4.59 \\
( \pm 1.92)\end{array}$ & Deniz et al. (2004) \\
\hline & $\begin{array}{c}0.85 \\
( \pm 0.17)\end{array}$ & 9.90 & 6.80 & 1.60 & Garay et al. (2009) \\
\hline & $\begin{array}{c}1.18 \\
\pm 0.08)\end{array}$ & $\begin{array}{l}13.60 \\
( \pm 1.7)\end{array}$ & $\begin{array}{c}5.68 \\
( \pm 1.09)\end{array}$ & $\begin{array}{c}3.96 \\
( \pm 0.08)\end{array}$ & Singh et al. (2011) \\
\hline & $\begin{array}{c}1.02 \\
\pm 0.28)\end{array}$ & $\begin{array}{r}11.00 \\
( \pm 3.0)\end{array}$ & $\begin{array}{c}8.60 \\
( \pm 3.0)\end{array}$ & $\begin{array}{c}1.20 \\
( \pm 0.2)\end{array}$ & Nasser et al. (2015) \\
\hline \multirow{3}{*}{$\begin{array}{c}\text { Rice straw (Oryza } \\
\text { sativa L.) }\end{array}$} & 0.89 & 14.80 & 6.40 & 6.36 & Tutus et al. (2004) \\
\hline & $\begin{array}{c}0.66 \\
( \pm 0.24)\end{array}$ & 4.90 & 1.90 & 1.50 & Garay et al. (2009) \\
\hline & $\begin{array}{c}0.83 \\
( \pm 0.15)\end{array}$ & $\begin{array}{c}10.89 \\
( \pm 1.30)\end{array}$ & $\begin{aligned} & 4.57 \\
&( \pm 0.1 .37)\end{aligned}$ & $\begin{array}{c}3.16 \\
( \pm 0.53)\end{array}$ & Kiaei et al. (2011) \\
\hline \multirow{3}{*}{$\begin{array}{l}\text { Maize stalks (Zea } \\
\text { mays spp) }\end{array}$} & 1.32 & 24.30 & 10.70 & 6.80 & Usta et al. (1990) \\
\hline & $\begin{array}{c}1.52 \\
( \pm 0.49)\end{array}$ & 8.40 & 4.40 & 2.00 & Garay et al. (2009 \\
\hline & $\begin{array}{c}0.88 \\
( \pm 0.23) \\
\end{array}$ & $\begin{array}{c}20.12 \\
( \pm 3.63) \\
\end{array}$ & $\begin{array}{r}10.92 \\
( \pm 3.86) \\
\end{array}$ & $\begin{array}{c}4.59 \\
( \pm 0.98) \\
\end{array}$ & Kiaei et al. (2011) \\
\hline \multirow{3}{*}{$\begin{array}{c}\text { Sunflower stalks } \\
\text { (Helianthus annuus L.) }\end{array}$} & 1.27 & 16.70 & 5.75 & 5.46 & $\begin{array}{c}\text { Khristova et al. } \\
(1998)\end{array}$ \\
\hline & $\begin{array}{c}0.96 \\
( \pm 0.21)\end{array}$ & $\begin{array}{c}22.84 \\
( \pm 3.96)\end{array}$ & $\begin{array}{c}11.12 \\
( \pm 3.32) \\
\end{array}$ & $\begin{array}{c}5.85 \\
( \pm 1.19)\end{array}$ & Kiaei et al. (2011) \\
\hline & $\begin{array}{c}0.96 \\
( \pm 0.3) \\
\end{array}$ & $\begin{array}{l}23.70 \\
( \pm 0.5)\end{array}$ & $\begin{array}{l}11.90 \\
( \pm 0.8) \\
\end{array}$ & $\begin{array}{c}5.90 \\
( \pm 0.3) \\
\end{array}$ & Rudi et al. (2016) \\
\hline \multirow{6}{*}{$\begin{array}{l}\text { Rapeseed straw } \\
\text { (Brassica napus L.) }\end{array}$} & 1.17 & 23.02 & 12.50 & 5.26 & Enayati et al. (2009) \\
\hline & 1.21 & 28.00 & 11.90 & 7.43 & Yousefi (2009) \\
\hline & 1.31 & 31.00 & 19.50 & 5.75 & $\begin{array}{l}\text { Hosseinpour et al. } \\
(2010)\end{array}$ \\
\hline & $\begin{array}{c}0.95 \\
( \pm 0.18)\end{array}$ & $\begin{array}{c}24.12 \\
( \pm 6.02)\end{array}$ & $\begin{array}{c}15.50 \\
( \pm 5.24)\end{array}$ & $\begin{array}{c}4.31 \\
( \pm 1.88)\end{array}$ & Kiaei et al. (2011) \\
\hline & $\begin{array}{c}1.20 \\
( \pm 0.26)\end{array}$ & $\begin{array}{c}13.10 \\
( \pm 3.34)\end{array}$ & $\begin{array}{c}8.60 \\
( \pm 2.82)\end{array}$ & $\begin{array}{c}2.25 \\
( \pm 0.47)\end{array}$ & $\begin{array}{c}\text { Tofanica et al. } \\
(2011)\end{array}$ \\
\hline & 1.03 & 28.00 & 19.10 & 4.91 & $\begin{array}{l}\text { Mousavi et al. } \\
(2013)\end{array}$ \\
\hline \multirow{4}{*}{$\begin{array}{l}\text { Sugarcane bagasse } \\
\text { (Saccharum } \\
\text { officinarum } \mathrm{L} \text {.) }\end{array}$} & 1.70 & 8.40 & 5.20 & 1.60 & $\begin{array}{l}\text { Khristova et al. } \\
(2006)\end{array}$ \\
\hline & $\begin{array}{c}1.51 \\
( \pm 0.08)\end{array}$ & $\begin{array}{l}21.40 \\
( \pm 1.6) \\
\end{array}$ & $\begin{array}{c}6.27 \\
( \pm 0.4) \\
\end{array}$ & $\begin{array}{c}7.74 \\
( \pm 0.2) \\
\end{array}$ & $\begin{array}{c}\text { Agnihotri et al. } \\
(2010)\end{array}$ \\
\hline & $\begin{array}{c}1.59 \\
( \pm 0.21) \\
\end{array}$ & $\begin{array}{c}20.96 \\
( \pm 0.24) \\
\end{array}$ & $\begin{array}{c}9.72 \\
( \pm 0.29) \\
\end{array}$ & $\begin{array}{c}5.64 \\
( \pm 0.33) \\
\end{array}$ & $\begin{array}{c}\text { Hemmasi et al. } \\
(2011)\end{array}$ \\
\hline & $\begin{array}{c}1.32 \\
( \pm 0.30)\end{array}$ & $\begin{array}{c}20.96 \\
( \pm 5.03)\end{array}$ & $\begin{array}{c}9.66 \\
( \pm 3.32)\end{array}$ & $\begin{array}{c}5.58 \\
( \pm 1.54)\end{array}$ & Kiaei et al. (2011) \\
\hline \multirow{2}{*}{$\begin{array}{c}\text { Coconut husk/coir } \\
\text { fibers } \\
\text { (Cocos nucifera) }\end{array}$} & $\begin{array}{c}0.69- \\
1.06\end{array}$ & $\begin{array}{l}17.52- \\
20.68\end{array}$ & $\begin{array}{l}10.71- \\
12.97\end{array}$ & 2.91-4.02 & Dam et al. (2006) \\
\hline & $\begin{array}{c}0.84 \\
\pm 0.17)\end{array}$ & $\begin{array}{c}20.09 \\
( \pm 3.84)\end{array}$ & $\begin{array}{c}13.59 \\
( \pm 3.26)\end{array}$ & $\begin{array}{c}4.41 \\
( \pm 1.14)\end{array}$ & Main et al. (2014) \\
\hline $\begin{array}{c}\text { Miscanthus } x \\
\text { giganteus stalks }\end{array}$ & $\begin{array}{c}0.97 \\
( \pm 0.08)\end{array}$ & $\begin{array}{c}14.2 \\
( \pm 2.5)\end{array}$ & $\begin{array}{c}5.90 \\
( \pm 2.2)\end{array}$ & $\begin{array}{c}4.10 \\
( \pm 0.8)\end{array}$ & $\begin{array}{c}\text { Ververis et al. } \\
(2004)\end{array}$ \\
\hline
\end{tabular}


Moreover, the calculated FW values in this study displayed a narrow to medium width, i.e., $15.17 \mu \mathrm{m} \pm 4.89 \mu \mathrm{m}$ for Miscanthus MG-S-02-V and $22.99 \mu \mathrm{m} \pm 5.20 \mu \mathrm{m}$ for the sunflower stalk (apart from the narrower fibers of rice, ranging from $10.77 \mu \mathrm{m} \pm 3.28$ $\mu \mathrm{m})$. The FW ranges of these AgRs are comparable to the hardwood FW range $(18.0 \mu \mathrm{m}$ to $30.0 \mu \mathrm{m}$ ) values (Tofanica et al. 2011). Referring to the rest of the examined parameters, the LD ranged from $4.52 \mu \mathrm{m} \pm 2.52 \mu \mathrm{m}$ (rice straw) to $13.23 \mu \mathrm{m} \pm 4.87 \mu \mathrm{m}$ (sunflower stalk), and the CTW ranged from $3.02 \mu \mathrm{m} \pm 0.95 \mu \mathrm{m}$ (rice straw) to $4.80 \mu \mathrm{m} \pm 1.48 \mu \mathrm{m}$ (sunflower stalk).

In general, the calculated FL dimensions in this work were shown to drastically vary in many cases, with the values reported from other researchers with analogous measurements on the same non-wood species. However, the remaining fiber dimensions values of the present study, i.e., the FW, LD, and CWT, were mostly found in agreement with the values reported by previous reference studies (as shown in Table 2). The notable FL differences with respect to the other studies could be explained by several reasons: (i) a variation in the total number of fibers measured to estimate the average morphological values; (ii) the crop varieties; (iii) the genotype or hybridization of the plant; (iv) software and calibration measurements; (v) the investigated parts of plants nodes, pith, internode; and (vi) the climate as well as the conditions of each collection site.

For instance, the FL increases from the base to the top for all non-wood plants, which might be a possible explanation for the observed average FL difference between the upper and lower rapeseed parts (Ververis et al. 2004). Furthermore, mature cereal straws and Miscanthus grass stems frequently do not contain pith at the internodes while retaining pith at the sections of the nodes. In other AgRs, e.g., maize, sugarcane, and sunflowers, the stem remains solid, and thus the proportion of pith content is relatively higher compared to cereal straws (Ilvessalo-Pfäffli 1995). Pith mainly contains parenchyma cells, while node parts of the non-wood plants contain mostly short fibers, and parenchyma cells. Their internode parts contain longer fibers including a certain number of vessels and parenchyma cells. Therefore, the removal of the pith from the stalks is expected to increase the average FL of pulp fibers from de-pithed material (Danielewicz et al. 2018). The examined macerated solutions in this work contained mixed specimens of all the plant parts, compared to other studies in which the examined materials were depithed, e.g., in Enayati et al. (2009), Hosseinpour et al. (2010), Kiaei et al. (2011), Tofanica et al. (2011), and Rudi et al. (2016). Additionally, a difference in the average FL values between the two Miscanthus genotypes was observed. Correspondingly, Dam et al. (2006) also noted slight differences in the fiber cell lengths among six coconut cultivars.

\section{Morphological Indices and Papermaking Potential}

The SR is an important parameter, that combined with the RR, helps to evaluate the morphological potential of lignocellulose fiber for paper production (Agnihotri et al. 2010). The SR is related to pulp digestibility, as well as the paper sheet density and tearing resistance (Ogbonnaya et al. 1997; Agnihotri et al. 2010). The higher an SR value is, the longer, thinner, and more flexible the fibers are considered to be, and subsequently, the stronger the tearing resistance of the paper sheet is expected to be (Ogbonnaya et al. 1997; Nasser et al. 2015). An optimal SR value range between 95 and 120 or between 55 to 75 for softwood and hardwood pulps, respectively, is recommended (Tofanica et al. 2011; Rudi et al. 2016; Gülsoy and Şimşir 2018). However, a non-wood plant source is considered sufficient for papermaking processes if the SR value is less than 70 and higher than 33 (Saeed et al. 2017a).

Tsalagkas et al. (2021). "Agricultural residues content," BioResources 16(4), 7935-7952. 7944 
The FC index is related to the individual elasticity of fibers and has a positive effect on the interfibrillar bonding behaviour of fibers, and eventually on the tensile and burst strength properties. Plant fibers can be classified as highly rigid fibers (an FC less than 30) through high elastic fibers (an FC greater than 75) (Tofanica et al. 2011; Gülsoy and Şimşir 2018). A higher rigidity of fiber has a negative influence on the mechanical strength properties of the resulting paper and provide porous papers with lower resistance (Nasser et al. 2015; Saeed et al. 2017a).

Plant material fibers with a RR less than 1 are suggested as preferable raw material for pulp and paper production, since these fibers are more flexible, easily collapsed, and less rigid, thus forming papers with improved strength. Previous studies indicated that fibers with a RR above 1 are stiffer, less flexible, exhibit lower interfibrillar bonding, and form bulkier papers (Agnihotri et al. 2010; Tofanica et al. 2011; Nasser et al. 2015; Gülsoy and Şimşir 2018).

A higher average FL, combined with a higher SR, a higher FC, and lower RR values indicate higher tensile, tear, and burst strength properties. Thus, non-wood plant sources that have these morphological characteristics should be considered optimal candidates as feedstocks in the pulp and paper industries.

Table 3. Estimated Morphological Indices Values of the Investigated Agricultural Residues (AgRs)

\begin{tabular}{|c|c|c|c|}
\hline Agricultural Residue Source & SR & FC & RR \\
\hline Wheat straw (Triticum spp.) & 46.31 & 49.44 & 0.98 \\
\hline Barley straw (Hordeum vulgare) & 43.86 & 45.67 & 1.17 \\
\hline Rice straw (Oryza sativa L.) & 49.90 & 41.97 & 1.34 \\
\hline Maize stalks (Zea mays spp) & 43.81 & 56.63 & 0.87 \\
\hline Sunflower stalks (Helianthus annuus L.) & 28.08 & 57.80 & 0.72 \\
\hline Rapeseed up. (Brassica napus L.) & 38.70 & 53.0 & 0.87 \\
\hline Rapeseed low. (Brassica napus L.) & 30.24 & 58.13 & 0.70 \\
\hline Sugarcane bagasse (Saccharum officinarum L.) & 58.11 & 51.72 & 0.88 \\
\hline Coconut husk/coir fibers (Cocos nucifera) & 38.32 & 60.8 & 0.62 \\
\hline Miscanthus $x$ giganteus stalks MG-S-02-V & 32.85 & 37.97 & 1.68 \\
\hline Miscanthus $x$ giganteus stalks MG-S-01-P & 46.21 & 45.30 & 1.18 \\
\hline
\end{tabular}

According to the RR values classified by Tofanica et al. (2011), wheat straw, rapeseed straw, maize stalk, sunflower stalks, and sugarcane bagasse fibers (with a RR of 0.50 to 1.0 ), are suitable for paper manufacturing products and are further characterized as flexible fibers with a medium thickness cell wall. The remaining AgRs, i.e., barley straw, rice straw, and miscanthus straw fibers (with a RR of 1.0 to 2.0), were found to be stiff, with thick cell walls, and small lumen fibers, and therefore are less suitable for paper products (Table 3). The morphological indices of the investigated AgRs revealed that Miscanthus MG-S-O2-V seems unsuitable as a pulp feedstock. However, wheat straw, maize stalks, rapeseed upper straw, sugarcane bagasse, and coconut husk were found to be suitable as a raw materials for pulp production. The remaining $\mathrm{AgR}$ sources can be 
classified as having intermediate suitability as a non-wood pulp feedstock. In addition, barley straw, rice straw, and Miscanthus MG-S-01-P had a RR greater than 1, whilst sunflower stalks and rapeseed lower part straw fibers had an SR less than 33.

Table 4. Morphological Indices Values per AgRs Source According to Literature References

\begin{tabular}{|c|c|c|c|c|}
\hline Agricultural Residue Source & SR & $\mathrm{FC}$ & $\mathrm{RR}$ & References \\
\hline \multirow{4}{*}{ Wheat straw (Triticum spp.) } & 55.9 & 30.45 & 0.21 & Deniz et al. (2004) \\
\hline & 85.76 & 68.69 & 0.47 & Garay et al. (2009) \\
\hline & 86.76 & 41.76 & 1.39 & Singh et al. (2011) \\
\hline & 96.4 & 78.2 & 0.28 & Nasser et al. (2015) \\
\hline \multirow{3}{*}{ Rice straw (Oryza sativa L.) } & 60.13 & 43.24 & 1.98 & Tutus et al. (2004) \\
\hline & 134.70 & 38.77 & 1.58 & Garay et al. (2009) \\
\hline & 76.58 & 41.96 & 1.38 & Kiaei et al. (2011) \\
\hline \multirow{3}{*}{ Maize stalks (Zea mays spp.) } & 54.32 & 44.03 & 1.27 & Usta et al. (1990) \\
\hline & 180.95 & 52.38 & 0.91 & Garay et al. (2009 \\
\hline & 44.08 & 54.27 & 0.84 & Kiaei et al. (2011) \\
\hline \multirow{3}{*}{$\begin{array}{c}\text { Sunflower stalks } \\
\text { (Helianthus annuus L.) }\end{array}$} & 76.04 & 34.43 & 1.90 & Khristova et al. (1998) \\
\hline & 42.03 & 48.68 & 1.05 & Kiaei et al. (2011) \\
\hline & 40.55 & 50.49 & 0.49 & Rudi et al. (2016) \\
\hline \multirow{6}{*}{$\begin{array}{l}\text { Rapeseed straw } \\
\text { (Brassica napus L.) }\end{array}$} & 50.83 & 54.30 & 0.84 & Enayati et al. (2009) \\
\hline & 43.21 & 42.5 & 1.25 & Yousefi (2009) \\
\hline & 42.26 & 62.9 & 0.59 & Hosseinpour et al. (2010) \\
\hline & 39.59 & 64.26 & 0.55 & Kiaei et al. (2011) \\
\hline & 36.8 & 68.21 & 0.51 & Tofanica et al. (2011) \\
\hline & 91.0 & 26.00 & 0.58 & Mousavi et al. (2013) \\
\hline \multirow{4}{*}{$\begin{array}{c}\text { Sugarcane bagasse } \\
\text { (Saccharum officinarum L.) }\end{array}$} & 202.4 & 61.9 & 0.61 & Khristova et al. (2006) \\
\hline & 70.56 & 29.30 & 2.46 & Agnihotri et al. (2010) \\
\hline & 75.86 & 46.37 & 1.16 & Hemmasi et al. (2011) \\
\hline & 62.97 & 46.08 & 1.15 & Kiaei et al. (2011) \\
\hline \multirow{2}{*}{$\begin{array}{l}\text { Coconut husk/coir fibers } \\
\text { (Cocos nucifera) }\end{array}$} & 45.55 & 61.99 & 0.58 & Dam et al. (2006) \\
\hline & 41.81 & 67.64 & 0.65 & Main et al. (2014) \\
\hline Miscanthus $x$ giganteus stalks & 68.3 & 41.5 & 1.3 & Ververis et al. (2004) \\
\hline
\end{tabular}

It should be noted that several morphological indices variations are documented in various literature (Table 4). The indicated differences appear to verify the necessity of an identical, integrated morphological analysis, to assess the suitability of the primary AgRs sources, which has been carried out in this work.

However, in addition to the morphological parameters of the fibers, high cellulose and low lignin contents are also essential evaluation criteria of a material planned to be used as a feedstock in pulp and paper industries and should be taken under consideration (Amode and Jeetah 2021). From a chemical point of view, cereals crop residues, i.e., wheat, maize, barley, rice, and rapeseed straw, contained an average lignin content of approximately $17 \%$ to $20 \%$ and an average cellulose content of $37 \%$ to $41 \%$. Sunflower straw exhibited intermediate lignin and cellulose compositions, i.e., 25.2\% lignin and $34.8 \%$ cellulose contents. Miscanthus grass has been reported to exhibit considerably high cellulose (46.3\%) content. On the contrary, sugarcane bagasse, which in this study displayed excellent morphological results, has been reported to hold relatively low cellulose (26.8\%) values (Thorenz et al. 2018). 


\section{CONCLUSIONS}

Agricultural residues (AgRs) have already been used or examined as feedstock materials for pulps. Fiber morphological analysis is one of the most essential prerequisites to illustrate their suitability for this purpose. However, several variations are documented in the literature relevant to their morphological characteristics and indices. In this study, it was attempted to deal with such considerations. Therefore, a comparative morphological analysis under an identical maceration and measurement analysis was performed among the major AgR crops worldwide.

1. From a morphology point of view, wheat straw, maize stalks, rapeseed straw, sugarcane bagasse, and coconut husk fibers were found to present the minimum potential required morphological parameters and therefore considered as the most suitable feedstocks for papermaking processes.

2. This outcome is very encouraging since these residues primarily account for a majority of the total residual biomass availability in their classified groups, i.e., cereals, oil, and sugar crops, respectively. It was also shown that the average rapeseed fiber length was slightly different, depending on the height of the plant.

3. Similarly, the average miscanthus fiber length was greatly influenced by the originated genotype.

\section{ACKNOWLEDGMENTS}

This work was funded by the 'Sustainable Raw Material Management Thematic Network - RING 2017', EFOP-3.6.2-16-2017-00010 project in the framework of the Széchenyi 2020 Program. The realization of this program is supported by the European Union and co-financed by the European Social Fund. The Article Publishing cost was covered by the Interreg Austria-Czech Republic program, project VALID (ATCZ226) 'Added Value from Residuals'. The authors kindly thank Sandor Miszkuly and Gabor Geri, the owners of Energianoveny Ltd., for kindly providing the Miscanthus raw material.

\section{REFERENCES CITED}

Agnihotri, S., Dutt, D., and Tyagi, C. H. (2010). "Complete characterization of bagasse of early species of Saccharum officinerum-co 89003 for pulp and paper making," BioResources 5(2), 1197-1214. DOI: 10.15376/biores.5.2.1197-1214

Ai, J., and Tschirner, U. (2010). "Fiber length and pulping characteristics of switchgrass, alfalfa stems, hybrid poplar and willow biomasses," Bioresource Technology 101(1), 215-221. DOI: 10.1016/j.biortech.2009.07.090

Albert, S., Padhiar, A., and Gandhi, D. (2011). "Fiber properties of Sorghum halepense and its suitability for paper production," Journal of Natural Fibers 8(4), 263-271. DOI: $10.1080 / 15440478.2011 .626236$

Amode, N. S., and Jeetah, P. (2021). "Paper production from Mauritian hemp fibres," Waste and Biomass Valorization 12, 1781-1802. DOI: 10.1007/s12649-020-01125-y

Bates, I., Plazonić, I., Seleš, V. R., and Barbarić-Mikočević, Z. (2020). “Determining the

Tsalagkas et al. (2021). "Agricultural residues content," BioResources 16(4), 7935-7952. 7947 
quality of paper substrates containing triticate pulp for printing industry," Nordic Pulp \& Paper Research Journal 35(2), 272-278. DOI: 10.1515/npprj-2020-0009.

Bentsen, N. S., and Felby, C. (2010). Technical Potential of Biomass for Energy Services from Current Agriculture and Forestry in Selected Countries in Europe, Americas and Asia (Landscape Working Papers No. 54-2010), University of Copenhagen, Frederiksberg, Denmark.

Bentsen, N. S., Felby, C., and Thorsen, B. J. (2014). "Agricultural residue production and potentials for energy and materials services," Progress in Energy and Combustion Science 40, 59-73. DOI: 10.1016/j.pecs.2013.09.003

Camia, A., Robert, N., Jonsson, R., Pilli, R., García-Condado, S., López-Lozano, R., van der Velde, M., Ronzon, T., Gurría, P., M'Barek, R., et al. (2018). Biomass Production, Supply, Uses and Flows in the European Union. First Results from an Integrated Assessment (Report No. EUR 28993 EN), Joint Research Centre, Ispra, Italy.

Cappelletto, P., Mongardini, F., Barberi, B., Sannibale, M., Brizzi, M., and Pignatelli, V. (2000). "Papermaking pulps from the fibrous fraction of Miscanthus x giganteus," Industrial Crops and Products 11(2-3), 205-210. DOI: 10.1016/S09266690(99)00051-5

Chen, X. (2016). "Economic potential of biomass supply from crop residues in China," Applied Energy 166, 141-149. DOI: 10.1016/j.apenergy.2016.01.034

Cherubin, M. R., Oliveira, D. M. d. S., Feigl, B. J., Pimentel, L. G., Lisboa, I. P., Gmach, M. R., Varanda, L. L., Morais, M. C., Satiro, L. S., Popin, G. V., et al. (2018). "Crop residue harvest for bioenergy production and its implications on soil functioning and plant growth: A review," Scientia Agricola 75(3), 255-272. DOI: 10.1590/1678992X-2016-0459

Confederation of European Paper Industries (CEPI) (2020). "Key statistics report 2019," (https://www.cepi.org), Accessed 24 July 2020.

Dam, J. E. G. v., Oever, M. J. A. v. d., Keijsers, E. R. P., Putten, J. C. v. d., Anayron, C., Josol, F., and Peralta, A. (2006). "Process for production of high density/high performance binderless boards from whole coconut husk - Part 2: Coconut husk morphology, composition and properties," Industrial Crops and Products 24(2), 96104. DOI: 10.1016/j.indcrop.2005.03.003

Danielewicz, D., Dybka-Stępień, K., and Surma-Ślusarska, B. (2018). "Processing of Miscanthus $x$ giganteus stalks into various soda and kraft pulps. Part I: Chemical composition, types of cells and pulping effects," Cellulose 25, 6731-6744. DOI: 10.1007/s10570-018-2023-9

Deniz, İ., Kırc1, H., and Ates, S. (2004). "Optimisation of wheat straw Triticum drum kraft pulping," Industrial Crops and Products 19(3), 237-243. DOI: 10.1016/j.indcrop.2003.10.011

de Assis, T., Pawlak, J., Pal, L., Jameel, H., Venditti, R., Reisinger, L. W., Kavalew, D., and Gonzalez, R, W. (2019). "Comparison of wood and non-wood market pulps for tissue paper application," BioResources 14(3), 6781-6810.

Elbersen, B. S., Startisky, I. G., Hengeveld, G. M., Schelhaas, M. J., Naeff, H. S. D., and Böttcher, H. (2012). Atlas of EU Biomass Potentials: Spatially Detailed and Quantified Overview of EU Biomass Potential Taking into Account the Main Criteria Determining Biomass Availability from Different Sources (IEE 08653 SI2.529 241), International Institute for Applied Systems Analysis, Laxenburg, Austria. Elmas, G., Gürboy, B., and Eray, İ. (2018). "Examining the pulp production 
compatibility of earlywood and latewood in willow (Salix excelsa) clones in terms of fiber morphology," BioResources 13(4), 8555-8568.

El-Sayed, E. S. A., El-Sakhawy, M., and El-Sakhawy, M. A-M. (2020). "Non-wood fibers as raw material for pulp and paper industry," Nordic Pulp \& Paper Research Journal 35(2), 215-230. DOI: 10.1515/npprj-2019-0064

Enayati, A. A., Hamzeh, Y., Mirshokraie, S. A., and Molaii, M. (2009). "Papermaking potential of canola stalks," BioResources 4(1), 245-256. DOI:

10.15376/biores.4.1.245-256

Ferdous, T., Quaiyyum, M. A., and Jahan, M. S. (2020). "Chlorine dioxide bleaching of nineteen non-wood plant pulps," Nordic Pulp \& Paper Research Journal 35(4), 569576. DOI: 10.1515/npprj-2020-0043

Food and Agriculture Organization of the United Nations (FAOSTAT). (2019). "Forestry production and trade," (http://www.fao.org/faostat/en/\#data/FO), Accessed June 2020.

Garay M., R. M., Rallo de la B., B. M., Carmona C., R., and Araya C., J. (2009). "Characterization of anatomical, chemical, and biodegradable properties of fibers from corn, wheat and rice residues," Chilean Journal of Agricultural Research 69(3), 406-415. DOI: 10.4067/S0718-58392009000300014

García-Condado, S., López-Lozano, R., Panarello, L., Cerrani, I., Nisini, L., Zucchini, A., Velde, M. V. d., and Baruth, B. (2019). "Assessing lignocellulosic biomass production from crop residues in the European Union: Modelling, analysis of the current scenario and drivers of interannual variability," GCB Bioenergy 11(6), 809831. DOI: $10.1111 / \mathrm{gcbb} .12604$

Gharehkhani, S., Sadeghinezhad, E., Kazi, S. N., Yarmand, H., Badarudin, A., Safaei, M. R., and Zubir, M. N. M. (2015). "Basic effects of pulp refining on fiber properties - A review," Carbohydrate Polymers 115, 785-803. DOI: 10.1016/j.carbpol.2014.08.047

Goel, K., Radiotis, T., Eisner, R., Sherson, G., and Li, J. (2000). "Switchgrass: a potential pulp fibre source," Pulp and Paper Canada -Ontario- 101(6), 41-45.

González, I., Alcalá, M., Arbat, G., Vilaseca, F., and Mutjè, P. (2013). "Suitability of rapeseed chemithermomechanical pulp as raw material in papermaking," BioResources 8(2), 1697-1708.

Gonzalo, A., Bimbela, F., Sánchez, J. L., Labidi, J., Marín, F., and Arauzo, J. (2017). "Evaluation of different agricultural residues as raw materials for pulp and paper production using a semichemical process," Journal of Cleaner Production 156, 184193. DOI: $10.1016 /$ j.jclepro.2017.04.036

Gregg, J. S., and Smith, S. J. (2010). "Global and regional potential for bioenergy from agricultural and forestry residue biomass," Mitigation and Adaptation Strategies for Global Change 15(3), 241-262. DOI: 10.1007/s11027-010-9215-4

Gülsoy, S. K., and Şimşir, S. (2018). "Chemical composition, fiber morphology, and kraft pulping of bracken stalks (Pteridium aquilinum (L.) Kuhn)," Drvna Industrija 69(1), 23-33. DOI: 10.5552/drind.2018.1725

Hemmasi, A. H., Samariha, A., Tabei, A., Nemati, M., and Khakifirooz, A. (2011). "Study of morphological and chemical composition of fibers from Iranian sugarcane bagasse," American-Eurasian Journal of Agricultural and Environmental Sciences 11(4), 478-481.

Hiloidhari, M., Das, D., and Baruah, D. C. (2014). "Bioenergy potential from crop residue biomass in India," Renewable and Sustainable Energy Reviews 32, 504-512. DOI: 10.1016/j.rser.2014.01.025 
Hosseinpour, R., Fatehi, P., Latibari, A. J., Ni, Y., and Sepiddehdam, S. J. (2010). "Canola straw chemimechanical pulping for pulp and paper production," Bioresource Technology 101(11), 4193-4197. DOI: 10.1016/j.biortech.2010.01.055

$\mathrm{Hu}, \mathrm{G} ., \mathrm{Fu}, \mathrm{S}$., and Liu, H. (2013). "Hemicellulose in pulp affects paper properties and printability," Appita Journal 66(2), 139-144.

Ilvessalo-Pfäffli, M-S. (1995). "Grass fibers (including papyrus and palms)," in: Fiber Atlas: Identification of Papermaking Fibers, T. E. Timell (ed.), Springer-Verlag, Berlin, Germany, pp. 269-291.

Jahan, M. S., Rahman, M. M., and Ni, Y. (2021). "Alternative initiatives for non-wood chemical pulping and integration with the biorefinery concept: A review," Biofuels Bioproducts and Biorefining 15, 100-118. DOI: 10.1002/bbb.2143

Jeetah, P., and Jaffur, N. (2021). "Coconut husk, a lignocellulosic biomass, as a promising engineering material for non-wood paper production," Journal of Natural Fibers DOI: 10.1080/15440478.2021.1889428

Jeetah, P., Golaup, N., and Buddynauth, K. (2015). "Production of cardboard from waste rice husk," Journal of Environmental Chemical Engineering 3, 52-59. DOI: 10.1016/j.jece.2014.11.013

Jiang, D., Zhuang, D., Fu, J., Huang, Y., and Wen, K. (2012). "Bioenergy potential from crop residues in China: Availability and distribution," Renewable and Sustainable Energy Reviews 16(3), 1377-1382. DOI: 10.1016/j.rser.2011.12.012

Kamoga, O. L. M., Kirabira, J. J., Byaruhanga, J. K., Godiyal, R. D., and Anupam, K. (2016). "Characteristics and evaluation of pulp and paper from selected Ugandan grasses for paper industry," Cellulose Chemistry and Technology 50(2), 275-284.

Kaur, D., Bhardwaj, N. K., and Lohchab, R. K. (2019). "Environmental aspect of using chlorine dioxide to improve effluent and pulp quality during wheat straw bleaching," Waste and Biomass Valorization 10, 1231-1239. DOI: 10.1007/s12649-017-0193-6

Khristova, P., Gabir, S., Bentcheva, S., and Dafalla, S. (1998). "Soda-anthraquinone pulping of sunflower stalks," Industrial Crops and Products 9(1), 9-17. DOI: 10.1016/S0926-6690(98)00008-9

Khristova, P., Kordsachia, O., Patt, R., Karar, I., and Khider, T. (2006). "Environmentally friendly pulping and bleaching of bagasse," Industrial Crops and Products 23(2), 131-139. DOI: 10.1016/j.indcrop.2005.05.002

Kiaei, M., Samariha, A., and Kasmani, J. E. (2011). "Characterization of biometry and the chemical and morphological properties of fibers from bagasse, corn, sunflower, rice, and rapeseed residues in Iran," African Journal of Agricultural Research 6(16), 3762-6767. DOI: 10.5897/AJAR10.752

Lal, R. (2005). "World crop residues production and implications of its use as a biofuel," Environmental International 31(4), 575-584. DOI: 10.1016/j.envint.2004.09.005

Langholtz, M., Stokes, B., and Eaton, L. (2016). Billion-Ton Report: Advancing Domestic Resources for a Thriving Bioeconomy, Volume 1: Economic Availability of Feedstocks (ORNL/TM-2016/160), U. S. Department of Energy Oak Ridge National Laboratory, Oak Ridge, TN.

Lavrič, G., Pleša, T., Mendizza, A., Ropret, M., Karlovits, I., and Gregor-Svetec, D. (2018). "Printability characteristics of paper made from a Japanese knotweed," in: Proceedings of the $9^{\text {th }}$ International Symposium on Graphic Engineering and Design 2018 Conference, 8-10 November, Novi Sad, Serbia, pp. 99-102.

Main, N. M., Talib, R. A., Ibrahim, R., Rahman, R. A., and Mohamed, A. Z. (2014). "Suitability of coir fibers as pulp and paper," Agriculture and Agricultural Science

Tsalagkas et al. (2021). "Agricultural residues content," BioResources 16(4), 7935-7952. 7950 
Procedia 2, 304-311. DOI: 10.1016/j.aaspro.2014.11.043

Marín, F., Sánchez, J. L., Arauzo, J., Fuertes, R., and Gonzalo, A. (2009). "Semichemical pulping of Miscanthus giganteus. Effect of pulping conditions on some pulp and paper properties," Bioresource Technology 100(17), 3933-3940. DOI:

10.1016/j.biortech.2009.03.011

Mousavi, S. M. M., Hosseini, S. Z., Resalati, H., Mandavi, S., and Garmaroody, E. R., (2013). "Papermaking potential of rapeseed straw, a new agricultural-based fiber source," Journal of Cleaner Production 52, 420-424. DOI:

10.1016/j.jclepro.2013.02.016

Nasser, R. A., Hiziroglu, S., Abdel-Aal, M. A., Al-Mefarrej, H. A., Shetta, N. D., and Aref, I. M. (2015). "Measurement of some properties of pulp and paper made from date palm midribs and wheat straw by soda-AQ pulping process," Measurement 62 , 179-186. DOI: 10.1016/j.measurement.2014.10.051

Ogbonnaya, C. I., Roy-Macauley, H., Nwalozie, M. C., and Annerose, D. J. M. (1997). "Physical and histochemical properties of kenaf (Hibiscus cannabinus L.) grown under water deficit on a sandy soil," Industrial Crops and Products 7(1), 9-18. DOI: 10.1016/S0926-6690(97)00034-4

Pereira, H., Santos, A. J. A., and Anjos, O. (2016). "Fibre morphological characteristics of kraft pulps of Acacia melanoxylon estimated by NIR-PLS-R models," Materials 9(8), 1-9. DOI: 10.3390/ma9010008

Przybysz, K., Małachowska, E., Martyniak, D., Boruszewski, P., Iłowska, J., Kalinowska, H., and Przybysz, P. (2018). "Yield of pulp, dimensional properties of fibers, and properties of paper produced from fast growing trees and grasses," BioResources 13(1), 1372-1387. DOI: 10.15376/biores.13.1.1372-1387

Pulkkinen, I., Fiskari, J., and Alopaeus, V. (2009). "The effect of hardwood fiber morphology on the hygroexpansivity of paper," BioResources 4(1), 126-141. DOI: 10.15376/biores.4.1.126-141

Reddy, K. O., Maheswari, C. U., Shukla, M., and Muzenda, E. (2014). "Preparation, chemical composition, characterization and properties of Napier grass paper sheets," Separation Science and Technology 49(10), 1527-1534. DOI: 10.1080/01496395.2014.893358

Ring, G. J. F., and Bacon, A. J. (1997). "Multiple component analysis of fiber length distributions," TAPPI Journal 80(1), 224-231.

Rousu, P. P., Karjalainen, M., Henricson, K. O., Niinimäki, J., Kajanto, I., and Backfolk, K. (2013). "Wheat straw pulp fractionation Part 1 . The effect of cells, vessels and fines on paper properties," Cellulose Chemistry and Technology 47(5-6), 443-453.

Rudi, H., Resalati, H., Eshkiki, R. B., and Kermanian, H. (2016). "Sunflower stalk neutral sulfite semi-chemical pulp: An alternative fiber source for production of fluting paper," Journal of Cleaner Production 127, 562-566. DOI: 10.1016/j.jclepro.2016.04.049

Saeed, H. A. M., Liu, Y., Lucia, L. A., and Chen, H. (2017a). "Suitable approach using agricultural residues for pulp and paper manufacturing," Nordic Pulp \& Paper Research Journal 32(4), 671-679. DOI: 10.3183/npprj-2017-32-04_p674-682_saeed

Saeed, H. A. M., Liu, Y., Lucia, L. A., and Chen, H. (2017b). "Evaluation of Sudanese sorghum and bagasse as pulp and paper feedstock," BioResources 12(3), 5212-5222. DOI: $10.15376 /$ biores. 12.3.5212-5222

Sharma, N., Bhardwaj, N. K., and Singh, R. B. P. (2020a). "Environmental issues of pulp bleaching and prospects of peracetic acid pulp bleaching," Journal of Cleaner

Tsalagkas et al. (2021). "Agricultural residues content," BioResources 16(4), 7935-7952. 7951 
Production 256, 1-11. DOI: 10.1016/j.jclepro.2020.120338

Sharma, N., Godiyal, R. D., Bhawana, Thapliyal, B. P., and Anupam, K. (2018). "Pulping and bleaching of hydro distillation waste of citronella grass (Cymbopogon winterianus Jowitt) for papermaking," Waste and Biomass Valorization 9(3), 409419. DOI: $10.1007 / \mathrm{s} 12649-016-9791-\mathrm{y}$

Sharma, N., Tripathi, S. K., and Bhardwaj, N. K. (2020b). "Utilization of sarkanda for making pulp and paper using elemental chlorine free and total chlorine free bleaching process," Industrial Crops and Products 149, 1-8. DOI: 10.1016/j.indcrop.2020.112316

Shatalov, A. A., and Pereira, H. (2006). "Papermaking fibers from giant reed (Arundo donax L.) by advanced ecologically friendly pulping and bleaching technologies," BioResources 1(1), 45-61. DOI: 10.15376/biores.1.1.45-61

Simmonds, F. A., and Hyttinen, A. (1964). Strength of Some Hardwood Pulps and Their Fiber Fractions (Report No. FPL-023), U.S. Department of Agriculture Forest Products Laboratory, Madison, WI.

Singh, S., Dutt, D., and Tyagi, C. H. (2011). "Complete characterization of wheat straw (Triticum aestivum PBW-343 L. Emend. Fiori \& Paol.) - A renewable source of fibres for pulp and paper making," BioResources 6(1), 154-177. DOI: 10.15376/biores.6.1.154-177

Sridach, W. (2010). "The environmentally benign pulping process of non-wood fibers," Suranaree Journal of Science and Technology 17(2), 105-123.

Thorenz, A., Wietschel, L., Stindt, D., and Tuma, A. (2018). "Assessment of agroforestry residue potentials for the bioeconomy in the European Union," Journal of Cleaner Production 176, 348-359. DOI: 10.1016/j.jclepro.2017.12.143

Tofanica, B. M., Cappelletto, E., Gavrilescu, D., and Mueller, K. (2011). "Properties of rapeseed (Brassica napus) stalks fibers," Journal of Natural Fibers 8(4), 241-262. DOI: $10.1080 / 15440478.2011 .626189$

Tutus, A., Deniz, I., and Eroglu, H. (2004). "Rice straw with oxide added soda-oxygenanthraquinone," Pakistan Journal of Biological Sciences 7(8), 1350-1354. DOI: 10.3923/pjbs.2004.1350.1354

Usta, M., Kırc1, H., and Eroglu, H. (1990). "Soda-oxygen Pulping of Corn stalks (Zea mays indurate Sturt.)," in: Proceedings of the TAPPI Pulping 1990 Conference, 1417 October, Toronto, Canada.

Ververis, C., Georghiou, K., Christodoulakis, N., Santas, P., and Santas, R. (2004). "Fiber dimensions, lignin and cellulose content of various plant materials and their suitability for paper production," Industrial Crops and Products 19(3), 245-254. DOI: 10.1016/j.indcrop.2003.10.006

Yousefi, H. (2009). "Canola straw as a bio-waste resource for medium density fiberboard (MDF) manufacture," Waste Management 29(10), 2644-2648. DOI:

10.1016/j.wasman.2009.06.018

Article submitted: June 15, 2021; Peer review completed: August 2, 2021; Revised version received and accepted: September 4, 2021; Published: October 12, 2021.

DOI: $10.15376 /$ biores.16.4.7935-7952 